\title{
KÖZÉPKORI RÉGÉSZET II. A KELTEZÉS MÓDSZERTANA
}

\author{
HOLL IMRE*
}

\begin{abstract}
Az interdiszciplináris követelmények után a keltezés leggyakoribb módjait vázoljuk, hangsúlyozva használatuk lehetöségeit és korlátait. Többféle módszer egybevetése esetén is az ásatási megfigyelés adatai az elsödlegesek.
\end{abstract}

Kulcsszavak: stratigráfia, stíluskritika, tipológia

A régészet számára a keltezés mindig központi kérdés - az írásos történelmi korok esetében egyre fontosabb, ha az objektumokat, leleteket történelmi események, illetve személyek környezetébe szeretnénk helyezni. A középkor esetében is csak a mind szúkebben meghatározandó idóhatárok adhatnak választ, magyarázatot - valamint kiindulást a kutatás továbbviteléhez. Eközben új értelmet kaphat a vizsgálat tárgya, legyen szó építési periódusról vagy a leletek szélesebb körú értelmezéséról. A lényeg az, hogy további interdiszciplináris lépésekre kapunk lehetőséget (bár a következtetések szubjektív hibákat, téves magyarázatokat adhatnak; lásd az I. részben).

Példaként említhetjük Kőszeg várának ásatását, ahol az északkeleti torony szintjének rétegét, használati idejét a 13. század második felére lehetett keltezni. Ez így egyúttal a teljes négy saroktornyos vár építési idejét is meghatározta. A következó, alig késóbbi építési periódusra a falelválásokból lehetett következtetni: ez az É-i palota. Ennek pontosabb korát már stíluskritika, illetve egy felirat (..+ GRAVE IWA...) segítségével lehetett Kőszegi Iván gróf személyéhez kötni. A Kőszegi család politikai kapcsolatai II. Otto-

* Holl Imre. MTA Régészeti Intézete, H-1014 Budapest, Úri u. 49.

1 A kérdés rövid áttekintése: WARBURTON 2008; FEHRING 1987, $37-45$. kárral egyben magyarázatot adtak arra is, hogy a hazánkban egyedülálló városi vár milyen külföldi megoldásokhoz kapcsolható.

\section{Stratigráfia ${ }^{1}$}

Elsődleges módszer az ásatás, egyben a stratigráfia használata. A lelőhely ásatással történő pusztítása, az azt takaró rétegek eltávolítása sajnos lehetetlenné teszi az újbóli utólagos kontrollt. Ezért a megfigyeléseket a lehetô legpontosabban rögzíteni kell (ásatási napló, rajz, fotó). Ez az ásató személyes felelőssége, ami állandó ott-tartózkodását igényli. Az egyes rétegek leleteit részletesen, késóbb azonosítható módon kell leírnia, a megfigyelésekhez kapcsolva (ezért egy leletjegyzék magában nem elegendó). A feltárás során megfigyelt feltöltés, rétegződés fontosságát a Közel- és Közép-Kelet ásatói ismerték fel, rámutatva, hogy a leletek mélysége önmagában még nem jelent kronológiát. A rétegek megfigyelése közben történik rajzi rögzítésük, megjelölésük, ezzel párhuzamos más jelenségek (gödör, cölöplyuk) megkülönböztetése - most már szintek, alaprajzok rögzítése. A változások miatt szükség lehet szintenként újabb alaprajz készítésére is. Mindezek nagyrészt szubjektív megfigyelések: pontosságuk az ásató gyakorlatától függ (az egyik például felismer két különböző réteget ott, 
ahol a másik csak egyet lát). A rétegek jelölése, számozása különféle módokon történhet; az egyszerú, felülról lefelé haladó számsor mellett - fóként német régészek - alkalmaznak olyan megoldást is, amikor nem kap minden külön metszet önálló számozást. Ehelyett azonos számot/jelzést kap mindegyik azonos korú réteg, függetlenül attól, hogy hol találtak rá. Ez a módszer minden elónye mellett is csak utólag alkalmazható, amikor valamiféle értékelés, felismerés lehetővé tette (például azonos építési periódus rétege, pusztulás rétege, fal melletti szint stb.). Elónye, hogy nagyobb ásatás publikálásakor a rajzok az egész területen jól mutatják a kronológiát alátámasztó fontos rétegek-szintek feltûnését, az olvasó könnyen tájékozódik. Egy másik módszer alkalmazásakor valamennyi réteg (és falmaradvány) folytatólagos sorszámot kap a feltárás egész menetét követve - akár éveken át. (Egy szám csak egyszer szerepel, hivatkozása egy helyet jelent, illetve annak leleteit.) Úgy vélem, a szelvényenkénti külön-külön számozás a legegyszerübb; érthetőbbé tehető, ha a rajz magyarázatánál a réteg összetétele-színe mellett más magyarázatot is adunk (pusztulási törmelék, utólagos feltöltés, kultúrréteg ... századi leletekkel stb.). Előfordulhat, hogy több hasonló összetételú réteget csak rajzuk kidolgozásával tüntetünk fel, de egy számot kapnak, mert nem észlelhetó periódusváltozás. Ha lehetséges, hosszabb szakaszok rétegrajzait összefüggóen kell ábrázolni, az álló falmaradványokat is feltüntetve, egyben szintezési adatokat is megadva. A szintadatok segíthetnek eltéró helyú falak, épületek összevetésében, az azonos építési periódus meghatározásában. (Nem a falkoronák, hanem a lábazat, járószint szintezése a döntő.) A rétegek keltezését leletanyaguk adja: a már máshonnét ismert korúak, illetve - ha vannak ilyenek - az éremleletek. Ezek felhasználásához azonban kritikai szemlélet szükséges (lásd az I. részben). ${ }^{2}$ Hogy a téves keltezések milyen történelmi következtetésekkel járnak, annak kirívó példái az erdélyi ispánsági várak - ezeket ugyanis szláv vagy román alapításúaknak tartották. ${ }^{3}$

2 Holl 2005a, 182, 191. Numizmatikai meghatározásból származó téves következtetésre lásd: Holl 2007, 235-237.

3 Részletesen összefoglalja: BónA 1986, 220-223, valamint uő.: Györffy György tanulmányának kiegészítése in: ArchÉrt 97 (1970), 232-233. Itt olvashatunk Dobokavár ásatásának szándékosan tévesen keltezett leleteiről a vár alsó rétegéből (nem 8-9. századi szláv, hanem a 10 . század végére, a 11. század elejére jól keltezhető ékszerek). A helynév is döntő: első ispánja Doboka, Csanád apja. A vármegye is erról kapta a nevét, ami másutt szintén bevett szokás volt.
A lelőhely rétegeinek analízise, a relatív vagy abszolút kronológia felállítása az egész ásatás kiértékelésének alapját képezheti; ezért itt szükség van az eredményes kritikai szemléletre. ${ }^{4}$

\section{Stíluskritika ${ }^{5}$}

A stílus vizsgálatának a régész számára két fó területe van: a nagy stíluskorszakok felismerése, valamint az egyéni stílusjegyek meghatározása és megkülönböztetése más hasonlóktól.

A múvészettörténetben általánosan használt alapvető keltezési módszer bizonyos esetekben a régészetben is nélkülözhetetlen. Hiszen még az olcsóbb fémtárgyak, illetve kerámiák egy része is rendelkezik bizonyos mértékủ múvészi-iparmúvészeti kidolgozással. Például az ötvöstárgyak vagy ezekhez közel álló bronzveretek, keresztek, kapcsok, a díszített mázas kerámiák és még inkább a kályhacsempék nagy része ${ }^{6}$ - így ilyen szempontból is vizsgálható keltezésük lehetósége. A stíluskritika segíthet annak megállapításában is, melyek lehettek az elsődleges korú darabok, illetve az ezeket már csak utánzó, kevésbé kvalitásos másolások, amelyek csak a divat folytatását jelentik. A korra jellemző stílusjegyek néha még egyszerú tömegárukon is feltúnnek, bár ilyenkor a keltezés csak tág időhatárt ad. Különösen az analógiák megtalálásakor szükséges a stíluskritika: azonos múhely/mester készíthette, vagy csupán átvétel, utánzás eredménye? Az elkülönítést a technológia vizsgálata segítheti, vagy más természettudományos módszerek - például az anyagvizsgálat.

A stílus változása jól követhető a korszakok divatjának alakulásával, a viselet megváltozásával, de ide tartozik például a fegyverzet is (bár ennek fejlődése nem puszta divatkérdés). A kályhacsempék esetében ez jól látható a különféle lovaslovagalakos daraboknál (ló és lovas védőfegyverzete). Például a késői lovasábrázolások sisaktípusa egyes pozsonyi csempéken elárulja, hogy

4 Holl 2007, 235-237.

Korábban is utaltam már a mûvészettörténeti stúdiumok szükségességére. Néha még ez sem elég. Akadt olyan kiváló múvészettörténész, akiről kollégái állították, hogy „,nincs szeme”, mert a finomabb stílusjegyeket nem érzékelte.

6 A kályhacsempék ily módon történô vizsgálatának példája a budai színes mázas csempék csoportjainak elkülönítése. Elöször valamennyit a budai Mátyás-kori múhely termékének tartották; ezt különböző stílusuk (és technológiájuk) kimutatásával lehetett cáfolni (legalább három különböző idejú mủhely, részben külföldi). Jellegzetes típusok stiláris vizsgálata, százéves hatásuk, majd népmúvészeti átformálásuk: Holl 2002, 7-30. 
a 16. század első felénél nem lehetnek korábbiak (pedig közlésükkor a „14-15. századra” keltezték). Az egyik reneszánsz-antikizáló sisakot hord, a másikon késői huszársisak látható.

\section{Tipológia $^{7}$}

A tipológia célja minden tudományban a rendteremtés-rendszerezés lehetőségének felhasználása, különféle módokon és eltérő célokkal. A régészetben a legrégebbi módszer az, amikor a nagy mennyiségben készített termékek szétválasztásacsoportosítása történik. Az épületek vagy tárgyak felosztásánál a közös jellemzők alapján lehet csoportokat alkotni, majd ezeken belül a forma módosulása, a díszítések elkülönítése típusokhoz, illetve variációkhoz vezet. (Típus helyett sokan analógiáról írnak, de az utóbbi szélesebb kört, kisebb eltéréseket jelenthet; a típusazonosság szúkebb.)

A keltezést a puszta tipológia önmagában nem teszi lehetővé; más módszerekkel keltezett objektumok vagy tárgyak jelentik a fogódzópontokat úgy a csoport, mint a típus esetében. Minél több ilyen keltezó eset van, annál biztosabb határok közé szorítható a keltezés. (Ennek kritikáját megint csak a keltező módszer kritikája segíti: milyen éremlelet, milyen stratigráfiai adat adta a kiindulópontot, a több adat milyen szórást ad -tól -ig meghatározással.)

Az alkalmazási terület nagyon sokféle, itt csak a legjellemzóbbekból sorolunk fel néhányat. Településformák, illetve az épületek-épülettípusok ugyancsak alkalmasak tipológiai rendszerezésre. Például a falusi házaknál a helyiségek száma, elrendezése, a kemencék-kályhák helye alapján itt fokozatos fejlődés mutatható ki. Egyes megoldások megjelenése is lehet korhoz kötött. Pontosabb kronológiára ez nem alkalmas, de fejlődési fázisokra, illetve régiók jellemzésére használható (1. kép).

Az olasz középkori régészetben az épületek kőfalainak vizsgálatakor találkozunk a különböző rakásmódok és kőfajták alapján történő tipologizálással. (Egy bizánci korú hely kőfalait a 6-11. századon belül húsz típusra osztották; egyegy századon belül három-öt típus szerepel. ${ }^{8}$ ) A módszer legfeljebb egy nagyobb épület, épületegyüttes esetében alkalmazható, a megfelelő, alapos rajzi felméréssel, fotókkal; távolabbra már nem lehet átvinni. Bizonyos jellegzetes falépítési

\footnotetext{
ADAMS 2008.

8 RAIMOND 2004, 490-494.
}

megoldásokat (kváderes, élszedett kváderes, téglafal stb.) az építészettörténetben egyébként régóta használnak korszakok meghatározására.

A tipológiai meghatározások használata falusi templomalaprajzok esetében ugyancsak általános gyakorlat, de csak tágabb keltezési lehetőségeket jelent. Relatív kronológiára már nem alkalmas. Irásos említések esetén párhuzamba szokták állítani.

A különböző fémtárgyak nagyobb sorozatokban ismert anyagát is gyakran rendezik tipológiai sorokba. Említhetjük itt a fegyvereket: a kardok esetében a markolatgomb különböző típusai adtak jó keltezési lehetőséget. Példaként említhetjük a ruhacsatok különféle divatos formáit; a ruta alakúakat például - az ismert ábrázolások, főként szobrok alapján - 1220 körül kezdték használni. Sarkaik eltérő kiképzése-dísze alapján a típusnak több variánsa van. Ezek esetében már a régészeti adatok vagy kincsleletek adhatnak közelebbi keltezést. ${ }^{9}$

Nagyobb mennyiségú leletanyag, például városásatások jól megfigyelt és keltezett rétegekből származó fémtárgyai esetében sikeres a tipológiai sorok összefoglaló bemutatása - ilyenekkel találkozunk a lengyel régészet esetében. Egyetlen település nagy mennyiségú és sokrétú anyagát (nyolc év ásatási anyagát) részletes tipológiai rendszerezéssel közölte az ásató; a stratigráfiával nyolc-kilenc periódust tudott elkülöníteni. ${ }^{10}$

A kerámiakutatás esetében a nagy mennyiségú, változatos anyag miatt gyakori a tipológiai rendszerezés (2. kép). Siegburg kőcserépkészítő múhelyeiből (hatéves ásatásból) három évszázadot átölelő hatalmas edényanyag került elő. Ezt feldolgozója formai tipológiával 97 táblán rendszerezte. Beosztása: csoportok, alcsoportok, ezen belül szériák (utóbbit nevezhetjük típusnak, kisebb formai eltérésekkel). Az egyes szériák keltezését négy periódussal határozta meg (12. század közepe - 14 . század). ${ }^{11}$

Az utóbbi évtizedekben fellendülő olasz középkori régészet a nagy mennyiségú és nagyon

\footnotetext{
Egy ausztriai kincslelet esetében a szerző az ékszereknél nem használja a típus szót. A csatokat fő formájuk alapján nevezi meg (kerek, csepp alakú, ruta alakú stb.), és variánsonként számozza. Ezen belül az eltérő díszítés alapján tesz különbséget. Egy variánst nem tekinthetünk egy típusnak, annyira különböző a megoldásuk. Így a ruta formájúak eltérő példányai a „13-14. század” keltezést kapják. Ezek közül az egyik - általunk típusnak nevezhetó - nálunk jól keltezhető (a 13. századra; valószínúleg a tatárjárás idején rejtették el). POKISCH-KÜHTREIBER 2004, 426-428; PARÁdI 1975, 119-161.

10 Démians D'ARChimbaud 1980. Ismertetése: ActaArchHung 37 (1985), 467-468.

11 BecKmann 1975.
} 
változatos kerámia - jelentős mértékben a mediterrán térségból származó import - kutatásában ért el számottevő eredményeket. Elsősorban technológia alapján (angób, mázak, festések, karcolt dísz stb.) állítanak fel csoportokat: például „ceramica grafitta, invetriata monocroma, invetriata dipinte in bruno, verde". Ezeket külön-külön használják import esetében is, mivel nagyon sok a hasonló technológiával készült kerámia. Egy csoporton belül különböző alakú edények vannak, hiszen technológiájuk azonos. Típusokat csak ezeken belül említenek, amikor megegyező rajzú-stílusú példányok esetleg keltezésre is módot adnak. Egy-egy csoport általában egy-két-három évszázadot is jelenthet; különböző csoportok ugyanakkor egy időben is készülhettek.
I.<smiles>C1=CCCC1</smiles><smiles>Ic1ccccc1</smiles>

II

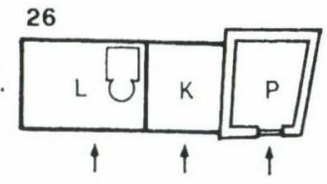

la.
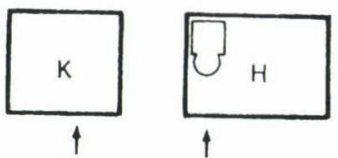

IIa.

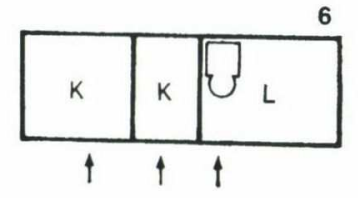<smiles>c1cc2ccc1CC1CCC2C1</smiles>
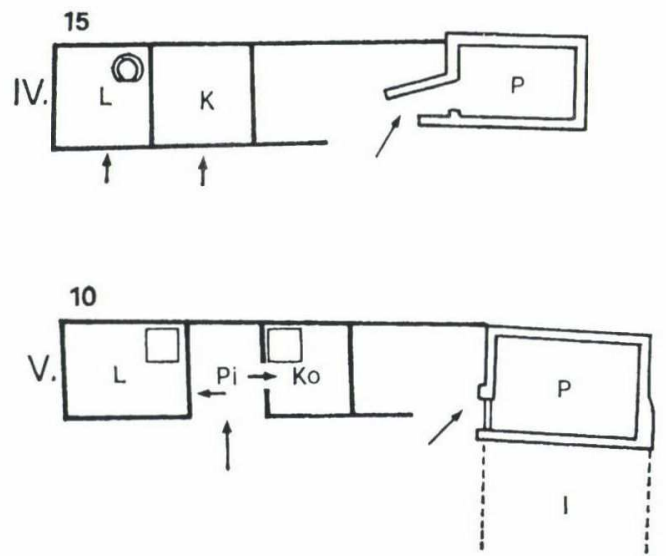

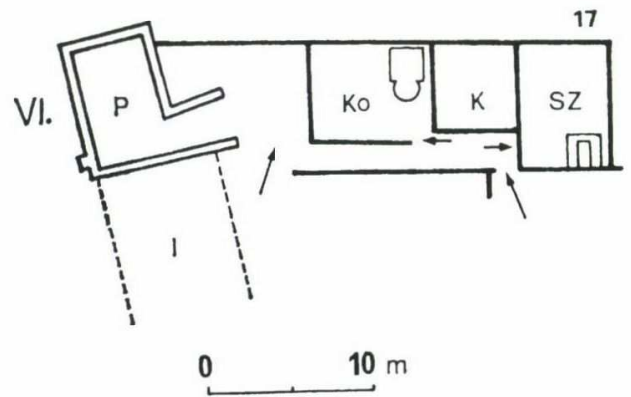

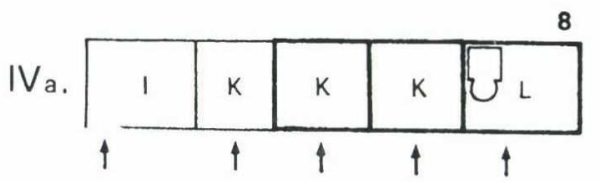

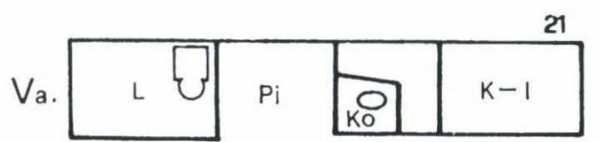

1. kép. A dunántúli falusi házak két fő típusának feltételezett fejlődési rendje, 13-15. század (HoLL 1979)

Fig. 1. The assumed development of the two main house-types from the Transdanubia region, $13^{\text {th }}-15^{\text {th }}$ century (HoLL 1979 )

$\begin{array}{ll}\mathrm{H}-\text { Hazz } & \text { Haus } \\ \text { L - Lakokonyha } & \text { Wohnküche } \\ \mathrm{K} \text { - Kamra } & \text { Kammer } \\ \mathrm{P}-\text { Pince } & \text { Keller } \\ \mathrm{SZ}-\text { Szoba } & \text { Stube } \\ \mathrm{I}-\text { Iställo } & \text { Stall } \\ \mathrm{Pi}-\text { Pitvar } & \text { Flur } \\ \text { Ko - Konyha } & \text { Küche }\end{array}$




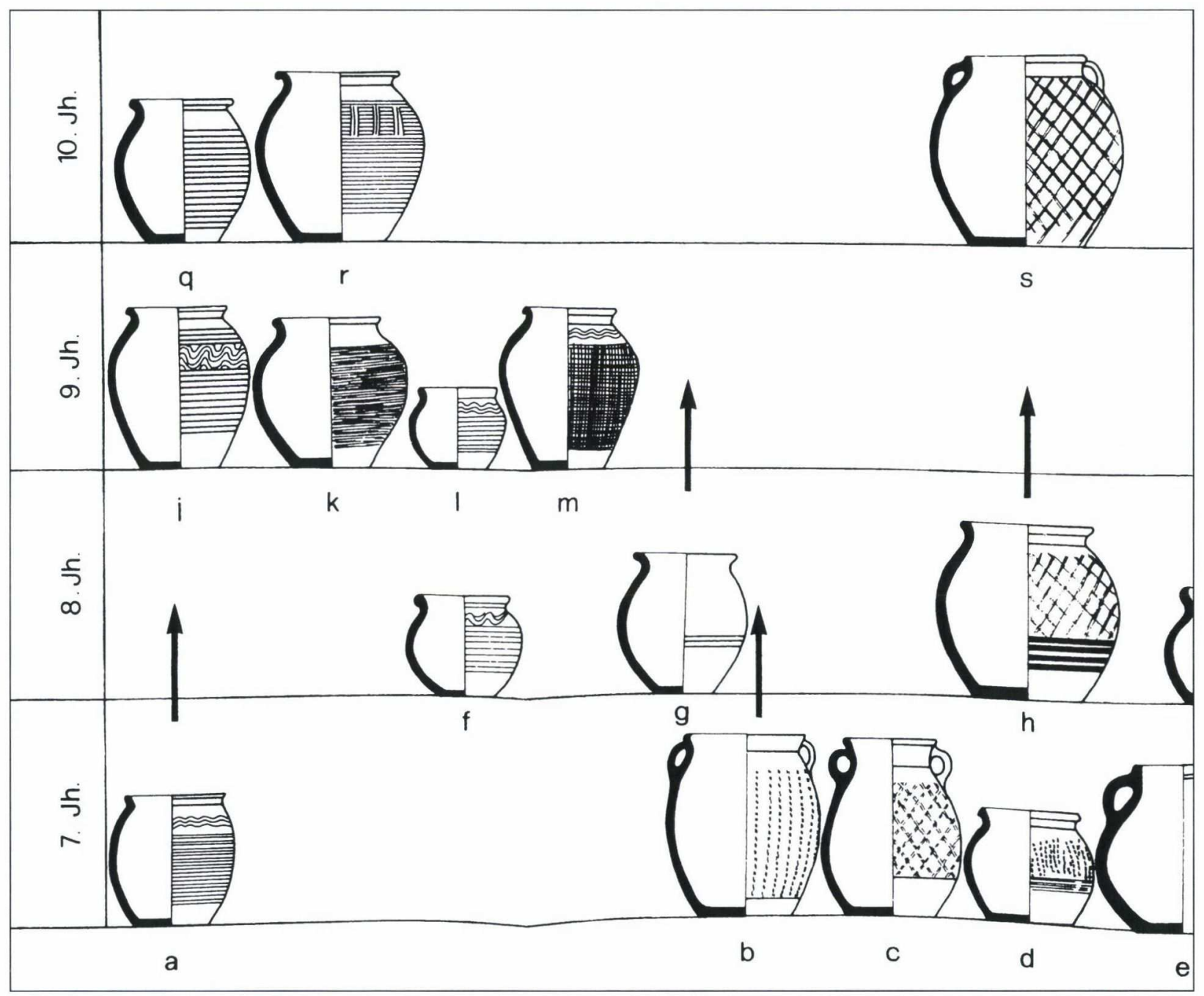

2. kép. Típuskronológia - fazekak a protobulgár korszakból, részlet (DONCEVA-PETKOVA 1990)

Fig. 2. Type chronology - pots from the Protobulgarian period, detail (DONCEVA-PETKOVA 1990)

(A csoporton belül néha római számokkal jelölt alcsoportokat különítenek el. ${ }^{12}$ ) Az itáliai kerámia sokrétúségére - egyben tipologizálásának nehézségére - példa lehet egy dél-itáliai lelőhely anyaga: itt csak a többszínú majolikát (maiolica policroma) húsz típusra osztják az edények alakja szerint. Az egyes dekorációs motívumok sorra vétele csak ez után következik.

Amikor a budai palota anyaga alapján magam próbáltam a kerámiákat feldolgozni, keltezett gödrök és rétegek alapján egy-egy százados beosztást adtam. A sok egyedi darab mellett a jellegzetes típusok ennél pontosabb keltezést is lehetővé tettek; másoknál - például a 13. századiaknál - az éremleletek még nem adtak szúkebb besorolást. ${ }^{13}$

A csehországi kerámia kutatásában ritkán próbáltak tipológiai elemzésekre támaszkodni - kivéve, amikor a pontosabb keltezés érdekében rö- vid időszakra datálható lelóhelyek (várak) kerámiáit vetették össze a peremprofilok alapján. A morva kőcserép sikeres tipológiai csoportosítását a későbbi ásatások is alátámasztják (Tip. IA-IB: fül nélküli poharak alakváltozása, ahol a kezdethez és a véghez éremleletes példányok besorolása adott jó alapot; Tip. IIA-IIB: a füllel ellátott példányok a kevéstől az egyre többfülúekig). ${ }^{14}$

A csehországi kályhacsempék hosszú időn keresztül közölt példányainál a szerző még azokban az esetekben sem használt tipológiai számo-

\footnotetext{
12 Ilyen csoportosításokkal közlik ásatási anyagukat például az ArchMed köteteiben a régészek Itáliában. - A bizánci kerámia cserépanyag, forma, technológia alapján, végül motívumok szerint: BÖHLENDORF-ARSLAN T. II. 2004, 94-150.

13 Holl 1963, 335-394.

14 Merinsky $1967,89-105$.
} 
zást, amikor egyetlen kályha anyagát közölte. Megelégedett az ábrázolt téma-motívum leírásával, ami alaki-stílusbeli jellemzést nem ad (így más lelóhelyek darabjaival csak a képek alapján hasonlíthatók össze). Összefoglaló monográfiájában ugyanezt az utat követte: a csoportosítás az ábrázolt témák szerint történt (különféle korúak). ${ }^{15}$

A legújabb kutatás nagy anyaggyújtés alapján végezte el az ausztriai korai grafitos kerámiák formáinak típusbeosztását. ${ }^{16}$

A Kárpát-medence középkori bográcsainak régóta folyamatos kutatását és ellentmondásait sikerült a korábbiakat meghaladó adatgyújtéssel, a keltezési támpontok összevetésével lezárni. ${ }^{17}$ A csoportosítás a készítési technikákat és a formákat vette alapul (A: kézzel készített, B: vödör alakú, C: fazék alakú, D: fémbogrács alakú). A két elsó csoport korai keltezésére még csak kevés példány használható. A C csoport formai fejlődése alapján a 12-13. századba helyezhető. Bár a negyedik csoport már a 11. században megjelenik - éremleletes rétegben -, többségük a 12-13. században készült. A csoporton belül tipológiai vizsgálatra csak az adhat lehetóséget, ha majd sikerül biztosan meghatározható fazekasmúhelyeket találni, egyéni jellegzetességekkel.

Az üvegek kutatása sok esetben alkalmazta eredményesen a tipológiai beosztást. Létrehozását a viszonylag nagy mennyiségú és sok évszázadra kiterjedó ásatási anyag tette szükségessé (viszonylag kisebb mértékben a múzeumi-iparmúvészeti gyưjtemények). Az egymástól jól megkülönböztethető alakok, díszítések és az üveg színe teszi lehetôvé a csoportosítást, ezen belül jellegzetes típusok elkülönítését. (Ez még a töredékes leletek egy részénél is alkalmazható.) Bár vannak általánosan használt, hosszú időn keresztül változatlanul alkalmazott formák (az olcsóbb tárolóedények, patikaedények stb.), többnyire jellegzetes alakúakkal találkozunk. Csoportjaik másfél vagy akár negyed századra is keltezhetők az új ásatások alapján. Korábban Németországban csak azokat a ritka példányokat tudták keltezni, amelyeket oltárokba falaztak, mert relikviatartók voltak. (Az ereklyét hitelesítő püspök pecsétje zárta a szájukat, megadva a befalazás idópontját.) A 16. századtól kezdve festett, majd csiszolt díszítésú üvegeken néha évszámos keltezés is feltúnik. A tipológiai beosztást

15 Hazblauer 1998, valamint az Archaeologia Historica egymást követö köteteiben.

16 SCHARRER-LISKA 2007.

17 TAKÁCS 1986. fóként az segíti, amikor nagy szériában készült, azonos alakú edényekkel találkozunk - ezt kereskedelmük igényelte, amely így volt kifizetődő. A muránói üvegeket például már a 13. században alakjuk-díszítésük alapján kapott nevük szerint rendelték a kereskedók. Az üvegek csoportosítását megnehezíti, hogy sok esetben nemzetközi öszszevetésük is hasonlóságokat mutat - ekkor csak a regionális csoportok elkülönítése segíthet. Utóbbiakat sokszor a készítési régió pontos meghatározása és keltezése nyomán lehet elkülöníteni, egyben kereskedelmi exportjukra is rámutatni. ${ }^{18} \mathrm{Az}$ utóbbi évtizedekben feltárt számos üveghuta segített a típusváltozatok felismerésében, egyben keltezésükben is (hibaforrás lehet azonban, hogy egy területen, például egy erdőben egymáshoz közel több huta múködhetett hosszabb ideig, ezért az írásos adatok nem mindig segítenek).

A magyarországi üvegek feldolgozása, rendszerezése szintén csoportok-típusok alapján készült, a formákon belül mindig újrakezdett típusszámokkal. Nagyobb részük egy-egy századra jellemző alakokat mutat ${ }^{19}$ (3-4. kép).

Gyakori, hogy változatos alakú-díszítésú üvegek feldolgozásánál nem típusokat neveznek meg, hanem csoportokat különítenek el, amelyek hosszabb időszakot jelentenek - néha több évszázadot. Ezen belül csak a feltúnően egyező alakú példányok adnak keltezési lehetőséget (ezeket akár típusoknak is nevezhetnénk). ${ }^{20}$

\section{A tipológiai vita}

Az 1940-es évektől kezdve különösen ÉszakAmerikában folyt vita a régészeti anyag osztályozásának értelméről - ezt nevezték tipológiai vitának. Mint W. Y. Adams megállapította, ${ }^{21}$ ennek kevés köze volt a gyakorlathoz. Az 1960-as évektől kezdve az európai ősrégészek vitája inkább a módszerek, mint a célok kihangsúlyozására törekedett. Általánosan elfogadott, hogy az ősrégészetben az osztályozás célja egyes kultúrák osztályozásának elősegítése, különösen kronológiai szempontból. Adams megállapítása szerint a tipológiai vita nagyrészt félresikerült, mert semmibe vette az osztályozás célját, a típusok komplexitását (materiális, tudati és reprezentációs oldalát). A valóságos anyagban végtelen sok

18 A készítési hely meghatározásának nehézségeiról: HoLL 2005a, 188

19 H. GYÜRKY 1984, 49-62; H. GYÜRKY 1986

20 Ilyen beosztás: Demians-D’́ ARCHIMBAud 1980, 10. jegyzet.

21 ADAMs 2008, 1019-1026, utalással a föbb irodalomra. 
La verrerie au $13^{\mathrm{e}}$ et $15^{\mathrm{e}}$ siècle dans les pays du Rhin d'après Verrerie de l'Est et de la France (1990)

presence en 1 - Alsace, 2 - Bourgogne, 3 - Champagne, 4 - Franche-Comte, 5 - Lorraine, 6 - Rhone-Alpes, 7 - Pays de Montbeliard

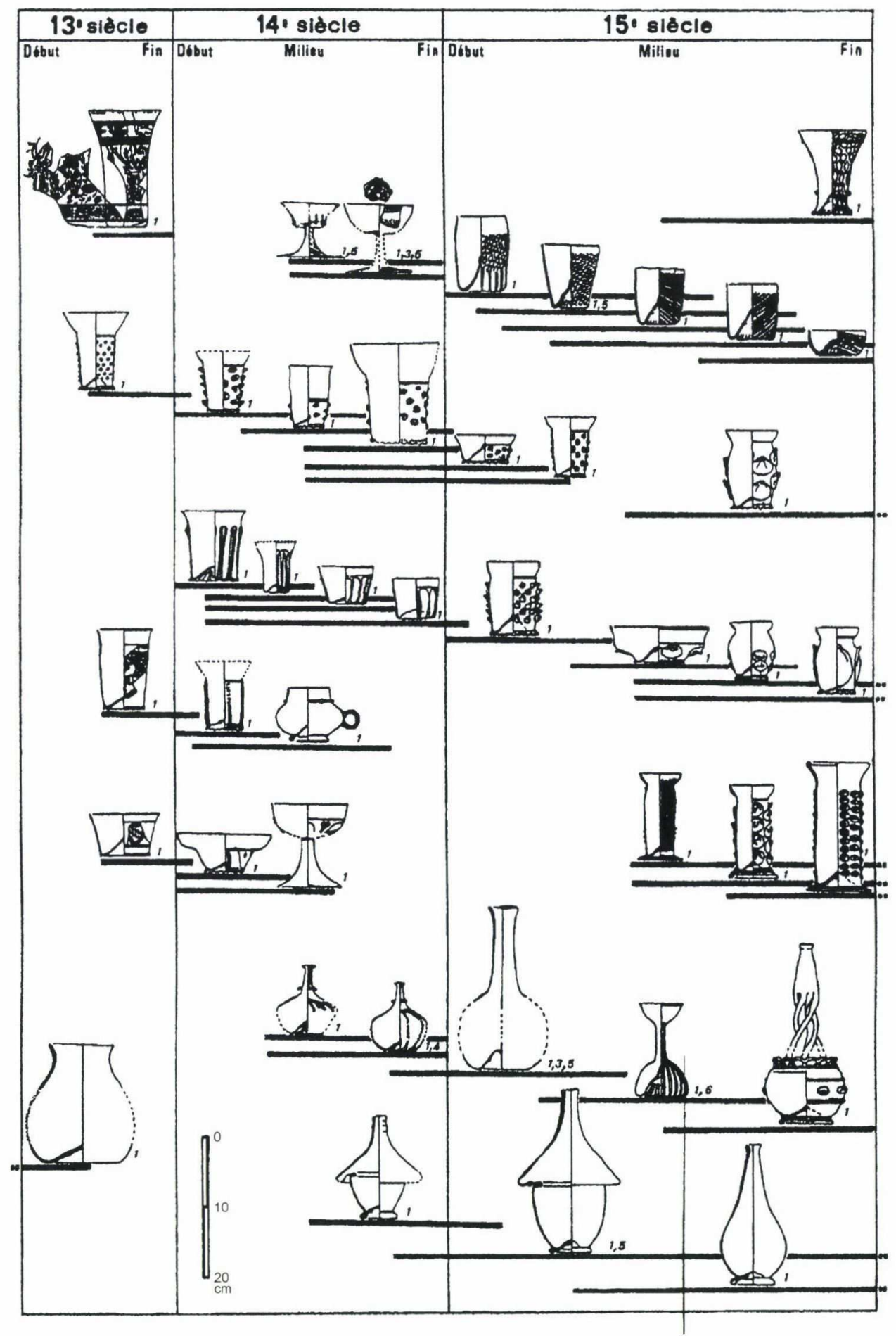

3. kép. Típuskronológia - üvegek Kelet- és Észak-Franciaországban, részlet (CABART 2003, Taf. 96) Fig. 3. Type chronology - medieval glass from Eastern and Northern France, detail (CABART 2003, Taf. 96) 
típus lehet jelen: a régész ezek közül választ célja szerint. Kiválaszt valamilyen jellemzót, ugyanakkor más jellemzőket figyelmen kívül hagy.
A legfontosabb, hogy a típus következetesen felismerhető, a tipológia alkalmazása pedig valamilyen célra hasznos legyen.22

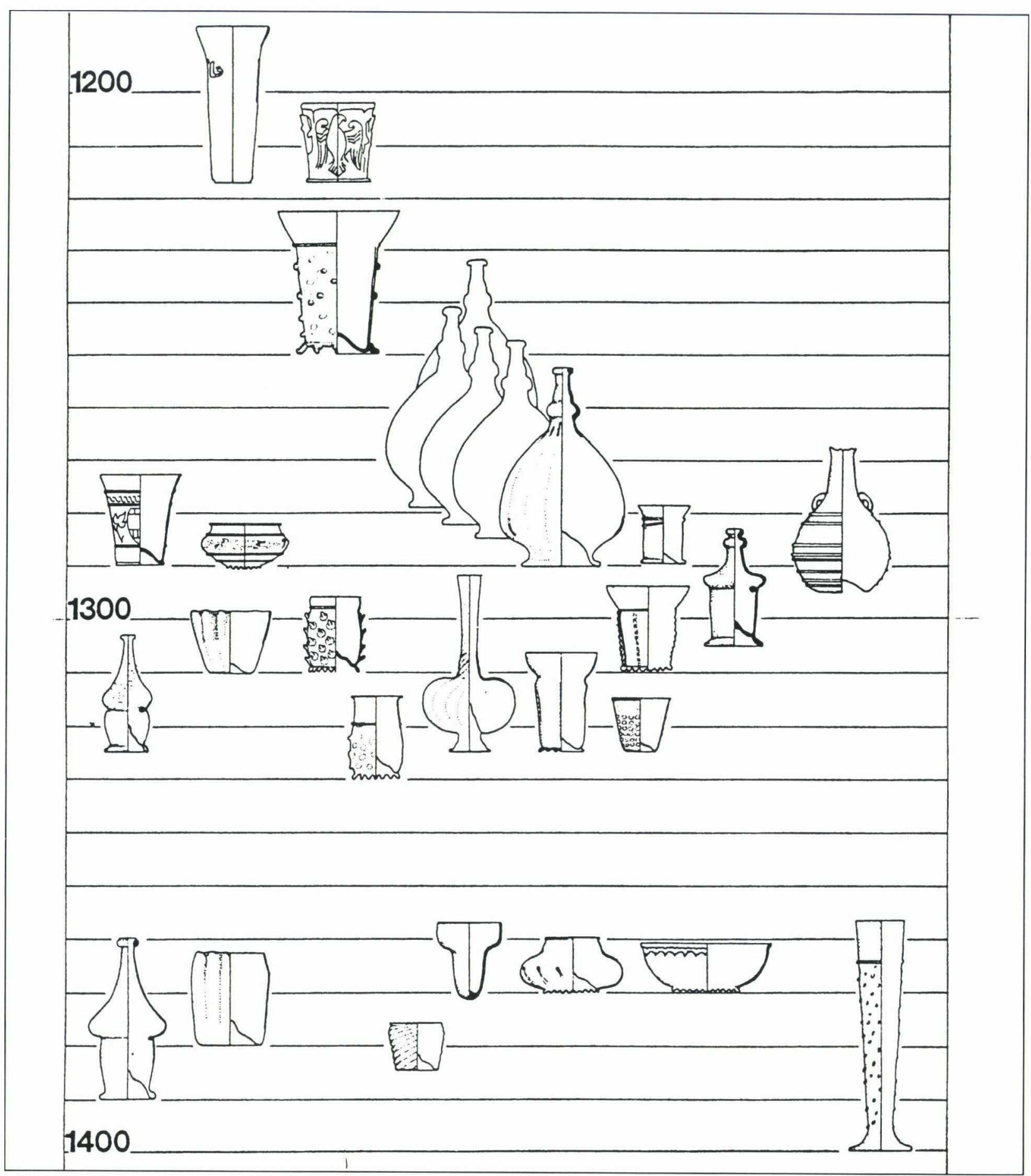

4. kép. Típuskronológia - középkori üvegek Magyarországon (H. GYÜRKY 1991)

Fig. 4. Type chronology - medieval glass in Hungary (H. GYÜRKY 1991)

22 ADAms 2008, 1024-1026: új módszereket proponáltak. Ennek eredményeként minden régész kifejleszti saját módszerét, saját osztályozási rendszerét leleteinek közléséhez. Megjegyezzük, hogy ezek egy részét - különösen a mediterrán kerámia esetében - sokan átvették, mert a technológián alapuló különbségeket felismerhetően rendszerezi. Saját anyagánál már mindenki ezen belül használ további tipizálást. 


\section{Csoport és típus}

A leletanyag esetében fóbb technológiai osztályozásuk után kerülhet sor a csoportok felállítására, majd ezeken belül formai-stílusbeli tipologizálásra. Ez lehet pusztán funkcionális (kerámiáknál: fazék, kancsó, korsó, csésze stb.), alakjuk szerint, majd azon belül. Mindez csak nagyobb korszakok összevetésekor ad kronológiai határokat (például a poharak viszonylag későn jelennek meg, alakváltozataik már új típusokat, variációkat mutatnak). Több lehetőséget kínál a nem használati szempont szerinti felosztás, ahol a forma, díszítési mód stb. kerül elótérbe. Itt is a csoport a nagyobb egység, a típusok ezen belül sorakoznak. Hiba, ha ezt megkerüljük, mert e nélkül a típus elveszti helyét, önkéntelenül olyan összehasonlításokhoz vezet, amelyek már nem állják meg a bizonyíthatóság próbáját (például különböző régiókból, különböző múhelyekbỏl származó anyagok, amelyeknek nem volt szerves kapcsolatuk, külön fejlödési vonalak eredményei). A csoport jelentheti egy bizonyos múhely termékeit vagy egymáshoz regionálisan jól kapcsolódó, azonos szintú mestereket hasonló termékekkel. Ha sikerül ilyeneket meghatározni, úgy kereskedelmi hatásuk távolra is bizonyítható. Jó példa erre a különböző németországi kőcserépkészítő múhelyek anyaga: formai-díszítési jellegük alapján jól elkülöníthetók. Ilyen a velenceimuránói üveg - számos múhelyével, de egységes stílusával -, illetve a cseh-morva üveg (nagyrészt még konkrét múhelyhez nem kötve.) Utóbbi példa mutatja, hogy egy régió anyaga - ha az importot elkülönítjük - már alkalmas tipologizálásra.

A regionális keretek között kiválasztott jellegzetes típusok és variációk sorozata - részben jól keltezett leletek bevonásával - kronológiai sorok készítését teszi lehetővé. Ez már megmutatja, hogy az idők folyamán milyen változások történtek: egyes típusok variációikkal tovább élnek, mások eltúnnek, újak jelennek meg (3-4. kép). ${ }^{23}$

A tipológia használatát sok régész az említett téves megítélések miatt kerüli, illetve nem ismeri alkalmazásának feltételeit, ezért értelmetlennek tartja. Ugyanakkor esetleg maga is csoportosításokat alkalmaz (ami önmagában is tágabb értelmú tipológia). Ez megfelelő csoportosítás nélkül, illetve nagyon sok évszázad vagy több régió leleteinek elkülönítése nélkül nem használható (lásd fentebb). A csoportot alkothatja egy meg-

23 CABART 2003. A táblázat összehasonlításai a római kortól az újkorig közlik a franciaországi üvegtípusok változását és kronológiáját. A középkor esetében regionális elkülönítést is adnak, mert nagy különbségek vannak köztük. határozott formájú eszköz, kerámiaféleség, ennek változatai akár egy-két évszázadot átölelő darabokkal, lehetóleg országos vagy kisebb regionális összesítéssel, múhelyek felismerése esetén még szúkebb keretekkel. Nagyobb területekről származó leletek összevetése tipológiai módszerrel azért lehet kétséges, mert a változatok talán nem egy egységes fejlődési rendszer eredményei, múhelyeik nem álltak kapcsolatban egymással, nem vették át egymás eredményeit. Ha vannak is hasonlóságok, azok csak az általánosan meghonosodott, a korral járó divatformák (a tágabb keltezésre ez persze még így is felhasználható). Sok használati eszköz, tárgy esetében látható, hogy bizonyos általános fejlódési trend (technológiai újítás) eredményeként országokon átívelő megoldásokat mutatnak - amelyeket a legkülönbözőbb múhelyek-mesterek egyaránt alkalmaztak. A középkori késeknél ilyen például a nyéltüskésnyéllapos megoldás változása; kerámiáknál pedig új használati követelményként a késő középkori poharak megjelenése. Ezek azonban még nem csoportok - csak regionális vagy helyi elkülönítéssel lehetnek azok.

Elófordulhat, hogy egy régész saját, lokális megjelenésủ leleteinek feldolgozásakor még nem tud csoportosító-tipológiai rendszert adni, ugyanakkor felismer nagyon jellegzetes „helyi típusokat”. Amikor cseh régészek a „prágai típusú pohár" nevet használják (15. század eleje), úgy ez egy bizonyos, jól felismerhetó, elkülönített formai megoldást jelent. Ugyanez a helyzet, ha a szlovák régészeknél „kassai típusú pohár” szerepel (15. század vége, 16. század eleje). Ezek helyi múhelyek „kitalált”, jellegzetes megoldásai, típusai. ${ }^{24}$ Hasonló okokból kapta egy igen jellegzetes, kisebb csoport a „brünni pohár" (Brünner Becher) elnevezést. A poharak jellemzóje a vastag, egyenes szár, talpkarima nélkül a bordázott pohártest alatt - ezzel élesen elkülönülnek a késó középkori cseréppoharaktól. Valószínúleg brünni fazekasok készítették a 15. század második felében. ${ }^{25}$ Az utóbbi esetek mutatják, hogy szélesebb körú tipológiai feldolgozás nélkül is lehet

24 Dragoun 1997, 321-329, 2-3. kép; Durisova-Kürthy 2007, 156-157. Az ilyen jellegzetes típus már keltezésre is használható. B. Polla korábban nevezett el késő középkori formákat: a "gótikus pohár" azonban a Felvidéken széles körben elterjedt, több múhely sajátja. Ráadásul nem egy típus, inkább tágan vett csoportok különböző megoldásokkal (a hivatkozott Zalužan szepességi poharai egészen mások). Polla 1979, 127-129, Tab. VIII. (Az itteni típust két variánsra osztotta.) Úgy vélem, a pozsonyi típus előzményét a bécsi 14-15. századi - ugyancsak redukált égetésủ - poharak jelentik. Exportjuk Morvaországban és Sopronban is kimutatható.

25 NeKudA-Reichertová 1968, 155-159, Tab. LXVII. 
jellegzetes lelettípusokat találni. A helyi, regionális típusok a kerámiáknál szintén kialakultak, jól meghatározhatók; jelentósebb helyi múhelyek termékei voltak. Ez egyben divatjelenség: a mesterek invencióját gyakran az akkor használt fémedények (ezüst, ón), poharak - néha üveg - különféle alakja táplálta. ${ }^{26}$ Utóbbiak a tehetós polgárság és a nemesség asztalának díszei, reprezentációs kellékei - általában nemzetközi megoldásokkal. Ezeket vette mintának a helyi fazekas.

\section{Abszolút keltezés}

A régészeti megfigyeléseken alapuló, sokszor csak tágabb keltezés (pl. egy évszázadra) biztosabb meghatározásához gyakran hívják segítségül a történeti adatokat, írásos forrásokat. Ezt az építészettörténet is előszeretettel alkalmazta, épületek feltárásakor pedig a régészek is használják. Ilyen lehet várak esetében az építés királyi engedélye, templomoknál és kolostoroknál pedig a pápai engedély évszáma. Ez azonban ritkán jelent egyetlen évet. Például az óbudai klarissza kolostor engedélye 1334-ból származik. Az építésre csak 1340 után került sor, a kolostorszárny pedig 1346-ra készült el. Magának a háromhajós nagy templomnak az építését 1350 körül fejezték be - azaz az első évszám után másfél évtizeddel. ${ }^{27}$ Ennél jóval bizonytalanabb támpontot adnak például a végrendeletekben rendszeresen szereplő „kegyes adományok" templomok vagy oltárok részére. Ezeket ma már a múvészettörténeti kutatás sem tekinti perdöntónek, mert javításra vagy a puszta fenntartásra is fordíthatták őket. A pápai búcsúengedélyek rendszerint szintén már meglévő egyházi épületre (ennek befejezésére, felszentelésére) vonatkoznak, tehát csak ante quem keltezést adnak.

A végrendeletek és hagyatéki leltárak viszont pontos képet adnak a polgárság és a nemesség ötvöstárgyairól, az értékesebb övek fajtáiról és a háztartás ónedényeiról, ezek alakjáról. Nyilvánvaló, hogy ezek nem az adott év, hanem korábban beszerzett javak leírásai, mégis keltezést adnak egy tágabb időszakra. Ráadásul sok olyan tárgyat is felsorolnak, amelyek tárgyi valóságukban már nem vizsgálhatók. ${ }^{28}$

26 A késő középkori ezüstpoharak közül a sima falú, a szája felé kissé szélesedő forma hatása is kimutatható (nem csak ónból); így például a bécsi fekete poharak egy csoportjánál, polírozott felülettel. A budai mesterek viszont zöld mázas felülettel és pecsétdíszekkel ellátva vették át, illetve festett majolika megoldással a 15. század utolsó harmadában. Ezekról legutóbb: Holl 2005b, 330, 371-375, Abb. 17, 34, 43.
Jó keltezést adnak a hazai várak modernizációját tervező olasz hadmérnökök fennmaradt tervrajzai - ráadásul a mérnök nevével. Egyeztetésük a feltárt váraknál jelenthet segítséget. Máskor viszont kiderül, hogy a terv nem valósult meg, illetve módosították. Jó példa erre Eger vára. Az írott forrásokban említett modernizálás Nádasdi T. nádor idejében Egervárnál (Zala m.) például 1539-1541 között történt - ehhez jól köthető az elkészült négy korai olaszbástya (S. Nagy E. kutatása).

Korábban már említettük a történeti adatok felhasználásánál szükséges forráskritikát, illetve a régészeti megfigyelés elsóbbségét. A sok közül itt csak a leggyakoribb, a tatárjárás mint pusztulási évszám használatára figyelmeztettünk. Várak és fóként a középkori falvak, templomok esetében ez általános módszer, általában el is fogadható. Számolhatunk viszont azzal is, hogy később, ha kisebb mértékben is, de tovább használták óket (például a várat mint refugiumot vagy a temetőt), vagy újratelepülés történhetett - a leletanyag erre feleletet adhat. A múvészettörténeti irodalomban a "Limoges-ból származó tárgyak" a tatárjárás után újjáépített templomok felszerelésében már közhelynek számítanak. ${ }^{29} \mathrm{~A}$ limoges-i, zománcozott ötvösmúvú körmeneti kereszteknél elfogadott a magyarországi leletek keltezése az 1250 körüli évekre. Legutóbb a Szarvas környéki kereszt esetében merült fel, hogy régebbi keltezése téves lehet, mert „az elrejtés a tatár inváziókor történhetett". A környék Árpádkori faluja a terepbejárás szerint ugyanis nem élt tovább. ${ }^{30} \mathrm{Az}$ azonos típusú budai töredék a Mária Magdolna-templomból azonban - az építkezés első periódusa szerint - csak az 1260-as években kerülhetett ide. ${ }^{31} \mathrm{Az}$ ismert limoges-i ötvöstárgyak zöme sajnos bizonytalan eredetú, az újabb ásatások (Ecsér, Helemba-sziget) ilyen jellegú keresztjeinek lemezei pedig nem datálhatók régészetileg. A francia analógiák, a népszerú kereskedelmi áruk az ottani meghatározás szerint azonban már a 13. század második harmadától kezdve készültek. ${ }^{32}$ Így a régészeti kutatás fel-

27 BERTALAN 1982, 155-156.

28 Soproni adatokat használtunk fel az óntárgyaknál: HoLl 1996, 71-88. A teljes végrendeleti anyag kiértékelését lásd: SZENDE 1990 .

29 Lovag 1983, 166-167.

30 JANKOVICH 1989, 365-367. Örménykút 7/118. lh. (régebben Szarvashoz tartozott). Az 1250 körüli keltezés mint az elpusztult felszerelési tárgyak pótlása: KovÁcs 1962, 97-101, 1. kép.

31 Bertalan V.-né 1971, 25, 15. kép.

32 KovÁCs 1968, 15. Itt közli az esztergomi kincstár ereklyetartó ládikáját, amelynek borítólemezei ugyanilyen stílusban vésett rozettákkal díszítettek: 28. kép. Megjegyzése: „Igen hasonló Fécamp-ban, XIII. század második negyede" (uo. 44.). 
adata lehet az egyes darabok esetében eldönteni, hogy ezek közül mi került korábban, illetve később hazánkba. ${ }^{33}$

Mint látható, a történeti adatok, pusztulások évszáma önmagában még nem biztos keltező; mindig összevetendő az ásatási megfigyelésekből, leletanyagból adódó keltezéssel. (Elpusztult váraknál számolhatunk kisebb mértékủ további használatukkal, településeknél újratelepüléssel.) A módszertani irodalomban mindig hangsúlyozták a régészeti úton kapott keltezési módok (rétegek, leletösszevetések) elsőbbségét; az írásos adatok önkényes felhasználásának direkt bizonyítéka ugyanis kétséges lehet. ${ }^{34}$

A történeti adatok bevonása a régészeti eredmények értelmezésébe - megfelelő kritikával mégis jelentősen bővíti tudásunkat, mert az ásatási megfigyelésekkel meg nem ragadható, másféle összefüggésekre világít rá, tágabb környezetbe, társadalmi-történeti kontextusba helyezi a régészeti eredményeket, újfajta magyarázatokhoz segít. Így már a történészek számára is használható eredményeket kaphatunk. ${ }^{35}$

\section{IRODALOM}

ADAMS, W. Y.

2008 Classification and typology. In: Encyclopaedia of Archaeology. Vol. 2, 1019-1026. Amsterdam-Oxford.

BECKMANN, S.

1975 Der Scherbenhügel in der siegburger Aulgasse. Bd. 1. Bonn.

BERTALAN, $\mathrm{H}$.

1982 Das Klarissenkloster von Óbuda aus dem 14. Jh. ActaArchHung 34, 151-176.

BERTALAN V.-NÉ

1971 Előzetes jelentés a Mária-Magdolna templom ásatásáról (Rapport provisiore sur des fuilles a l'église Marie-Madelaine). BudRég 22, 419-428.

BÓNA I.

2006 Erdély benépesülése a 10-11. században. In: Makkai L. (szerk.): Erdély története. 1. kötet. Budapest, 220-223.

BÖHLENDORF-ARSLAN, B.

2004 Glasierte byzantinische Keramik aus der Türkei. T. II. Istanbul.

H. CABART

2003 Aide-memoire du verre. Societé Archéologique Champenoise. Bull. Scientifique - Études et Travaux. 96, Nr. 2.

DÉMIANS D’ARCHIMBAUD, G.

1980 Les fouilles de Rougiers. Éd. du C.N.R.S. Paris. (Ismertetése: ActaArchHung 37, 467-468.)

DONCEVA-PETKOVA, L.

1990 Die Keramik der Saltovo-Majaki-Kultur. VariaArchHung III. 80. Budapest.

DRAGOUN, Z.

1997 Specificky typ poháru z pražskỳch nalezů. AHSb 22, 321-329, 2-3. kép.

DURISOVA, M.-KÜRTHY, L.

2007 Pamiatkovỳ vỳskum v Košiciah. AHSb 32, 156-157.

FEHRING, G. P.

1987 Einführung in die Archäologie des Mittelalters. Darmstadt.

H. GYÜRKY K.

1984 A 14. sz. üvegtípusai a budai régészeti leletanyagban (Glastypen aus dem 14. Jh. im archäologischen Fundmaterial von Buda). BudRég 26, 49-62.

1986 Az üveg. Katalógus. Monumenta Historica Budapestiensia V. Budapest.

1991 Üvegek a középkori Magyarországon (Gläser in mittelalterlichen Ungarn). BTM Múhely 3. Budapest. HazBlaUer, Z.

1998 Krása středověckýh kamen. Praha.

33 Még az 1970-es években hívta fel rá a figyelmet Baranyai B.né, hogy a múvészettörténészek a középkori régészek művészettörténeti képzést is kapott tagjaitól várhatnak segítséget.

34 Fenring 1987, 48; Holl 2005a, 192. Az ilyen kérdésekről egy történész szemével lásd: WENSKUS 1979, 634-657. A történész és a régész kutatása együtt kell haladjon, tủzzenek ki közös témákat. Ezt néhány északnémet városnál (Lübeck, Hanzavárosok) már megvalósították.

35 WeNSKUs 1979, 634-657. - Az itt nem tárgyalt természettudományos vizsgálatok tág alkalmazási köréröl lásd az Archaeometry c. folyóirat számos évfolyamát. 
Holl I.

1963 Középkori cserépedények a budai palotából (Mittelalterliche Keramik aus dem Burgpalast von Buda). BudRég 20, 335-394.

1996 Ónöntők a XV. századi Sopronban. In: Környei A. (szerk.): Tanulmányok Csatkai Endre emlékére. Sopron, 71-88.

2002 Középkori kályhacsempék: Egy 120 éves kutatási terület. In: Havassy P. (szerk.): Gerencsérek, kályhások, túzvigyázók. Gyula, 7-30.

2005a Középkori régészet: egy interdiszciplináris tudomány módszerei (Medieval archaeology: methodical questions of an interdisciplinary field). ArchÉrt 130, 181-194.

2005b Tischgerät im spätmittelalterlichen Buda. ActaArchHung 56, 311-384.

2007 Anjou-kori kályhacsempék (Stove tiles of the Angevin period). ArchÉrt 132, 219-240.

JANKOVICH D.

1989 7/118. lh. In: Makkay J. (szerk.): Békés megye topográfiája. MRT 8. Budapest, 365-367.

KOVÁCs É.

1962 Limoges-i keresztek Magyarországon. MúÉ 11, 97-101.

1968 Limoges-i zománcok Magyarországon. Budapest.

LOVAG Zs.

1983 Limoges-i mintára készült magyarországi körmeneti keresztek (Prozessionskreuze nach Limoges-Vorbildern in Ungarn). FolArch 34, 166-177.

MERINSKY, Z.

1967 Přehled typú lostické keramiky. Vlastivedny Vestnik Moravsky. c. 2-3, 21, 89-105.

NEKUDA, V.-REICHERTOVÁ, K.

1968 Středověká keramika v Čechách a na Moravé. Brno.

PARÁDI N.

1975 Pénzekkel keltezett XIII. századi ékszerek (Münzdatierte Schmuckstücke aus dem 13. Jh.). FolArch 26, 119-161.

POKISCH, B.-KÜHTREIBER, T.

2004 (Hrsg.): Der Schatzfund von Fuchsenhof. Linz, 426-428.

Polla, B.

1979 Bratislava, Západné suburbium. Bratislava.

RAIMOND, C.

2004 Per una atlante crono-tipologico. ArchMed 31, 490-494.

SCHARRER-LISKA, G.

2007 Die hochmittelalterliche Grafitkeramik in Mitteleuropa und ihr Beitrag zur Wirtschaftsgeschichte. Monographien RGZM, Bd. 68.

SZENDE K.

1990 A soproni polgárság anyagi kultúrája a késő középkorban. AETAS 3. Szeged.

TAKÁCS, M.

1986 Die arpadenzeitlichen Tonkessel im Karpatenbecken. Varia ArchHung I.

WARBurton, D. A.

2008 Stratigraphic analysis. In: Encyclopaedia of Archaeology. Vol. 3, 2101-2111.

WENSKUS, R.

1979 Randbemerkungen zum Vehältnis von Historie und Archäologie. In: H. Jankuhn-R. Wenskus (Hrsg.):

Vorträge und Forschungen. Bd. 22. Sigmaringen, 634-657. 


\section{MEDIEVAL ARCHAEOLOGY II. METHODOLOGY OF DATING}

\section{IMRE HOLL}

Following the topic of the previous paper (HoLL 2005a), we discuss questions of methodology - in this paper focusing on archaeological dating, considering possible sources of error, and critical use of the results.

The most important, primary method is stratigraphy, which could establish the relative dating of the finds. Stratigraphical protocols should be followed through the excavations, and observations should be documented properly, as this is the cornerstone of authenticity, and thus one of the main responsibilities of the excavator.

Critical analysis of style might be helpful for some archaeological material, especially for finding analogies. It helps with the material with artistic qualities - goldsmith's work, ornamental pottery, stove tiles, architectural carved stones - too: in recognising workshops, or establishing dating.
Although there are researchers, who deny the applicability, or refrain from using tipology, it is fundamental, used together with stratigraphy, for dating many finds. It uses stratigraphic information itself. Tipology is often unable to provide better dating than $50-100$ years, but for certain types it can be more precise (in these cases datings are used even by those who would not attempt using tipology otherwise). The preconditions of tipology are: a priori grouping, and defining types within the groups, regional data collection, use of well-dated finds. Useful not only for dating, but can help finding regional/cultural differences, or finding destinations of long distance commerce.

The use of written sources could help in absolute dating - but one needs to know its limitations (see HolL 2005a, 181-182, also in the case of pictures). 